\title{
FZD9 wt Allele
}

National Cancer Institute

\section{Source}

National Cancer Institute. FZD9 wt Allele. NCI Thesaurus. Code C51451.

Human FZD9 wild-type allele is located in the vicinity of $7 q 11.23$ and is approximately $2 \mathrm{~kb}$ in length. This allele, which encodes frizzled-9 protein, plays a role in Wnt signal transduction and may be involved in tissue polarity and development. Heterozygous deletion of the FZD9 gene may contribute to the Williams syndrome phenotype. 